\title{
Production and Use of Heteroptera Predators for the Biological Control of Eucalyptus Pests in Brazil
}

\section{Jose Cola ZANUNCIO ${ }^{\star \star}$, Wagner de Souza TAVARES ${ }^{2}$, Bianca Vique FERNANDES ${ }^{3}$, Carlos Frederico WILCKEN ${ }^{4}$, Teresinha Vinha ZANUNCIO ${ }^{1}$}

${ }^{1}$ Departamento de Biologia Animal, Universidade Federal de Viçosa 36570-000, Vicosa, Minas Gerais State- BRAZIL

2Departamento de Fitotecnia, Universidade Federal de Viçosa 36570-000, Viçosa, Minas Gerais State- BRAZIL

3Vallourec \& Mannesmann Florestal Ltda, Centro de Apoio a Pesquisa e Desenvolvimento Florestal 35774-000, Paraopeba, Minas Gerais State- BRAZIL

4Departamento de Produção Vegetal, Universidade Estadual Paulista "Júlio de Mesquita Filho" 18603-970, Botucatu, Sao Paulo State- BRAZIL

^Corresponding author: zanuncio@ufv.br

\begin{abstract}
The Asopinae predators of Eucalyptus spp. (Myrtaceae) pests in Brazil include Brontocoris tabidus, Podisus distinctus, Podisus nigrispinus, and Supputius cincticeps (Heteroptera: Pentatomidae). These insects feed on the larvae and pupae of Coleoptera and Lepidoptera defoliators. Asopinae predators are reared in the laboratory in wooden cages with wood screens on the upper and lateral sides and the front closed with a glass door, whereas, in the field they are raised in organza bags with branches of Eucalyptus spp. or Psidium guajava (Myrtaceae). An alternative prey, such as Tenebrio molitor (Coleoptera: Tenebrionidae) pupae and Musca domestica (Diptera: Muscidae), or Bombyx mori (Lepidoptera: Bombycidae) larvae, or the natural prey Anticarsia gemmatalis (Lepidoptera: Noctuidae), and Thyrinteina arnobia and Thyrinteina leucocerae (Lepidoptera: Geometridae) caterpillars may be provided to the nymphs of predators in cages and/or rearing bags. Vallourec \& Mannesmann Forest Ltda. has two laboratories to mass rear $M$. domestica to produce annually 300,000 individuals of $P$. nigrispinus which are released with or without pests in the field. In the first case, predators are released after detection of the pest by a monitoring process, which is the first major step in integrated pest management (IPM). This predator is efficient when the pest population level is below the economic injury level, i.e., nine caterpillars/100 leaves of Eucalyptus spp. Releasing are made in outbreaks every $10 \mathrm{~m}$ and the population increase of this predator can control pests. Podisus nigrispinus usually prey on 4-5 first and second instars larvae or 2-3 fourth and fifth instar caterpillars per day. Asopinae predators are reared and released in the field to control pests in the Eucalyptus spp. plantations of the Vallourec \& Mannesmann Forest Ltda. in Brazil.
\end{abstract}

Keywords: Asopinae, biodiversity, biological control, predators, sustainability.

Zanuncio JC, Tavares WS, Fernandes BV, Wilcken CF, Zanuncio TV (2013) Production and Use of Heteroptera Predators for the Biological Control of Eucalyptus Pests in Brazil. Ekoloji 23(91): 98-104.

\section{INTRODUCTION}

Asopinae predators of Eucalyptus spp. (Myrtaceae) pests in Brazil include the Brontocoris tabidus Signoret, 1852, Podisus distinctus Stäl, 1860, Podisus nigrispinus Dallas, 1851, and Supputius cincticeps Stäl, 1860 (Heteroptera: Pentatomidae) (Lemos et al. 2010a, Soares et al. 2011) (Fig. 1). These insects feed on the larvae and pupae of Coleoptera and Lepidoptera defoliators and on the nymphs and adults of Thaumastocoris peregrinus Dellape \& Carpintero, 2006 (Hemiptera: Thaumastocoridae) (Souza et al. 2012).

\section{MATERIAL AND METHODS}

The Asopinae predators are reared in wooden cages $(30 \mathrm{~cm} \times 30 \mathrm{~cm} \times 30 \mathrm{~cm})$ with a wood screen on the upper and lateral sides with the front enloosed with a glass door. The bottom of the cages are lined with paper to facilitate cleaning. Branches of Eucalyptus spp. are placed in the cages for $S$. cincticeps because this species needs plants (Lemos et al. 2009b). The Asopinae predators can also be reared in the field in organza bags with branches of the Eucalyptus spp. or Psidium guajava L. (Myrtaceae) (Lemos et al. 2009a, 2010b). The egg masses of these insects are removed daily from the cages and/or bags and maintained in Petri dishes until the nymphs reach second instar (Fig. 2).

Food is provided according to the rearing need to 
reduce cannibalism (Pires et al. 2011). The prey are placed on the top and bottom of rearing cages with moistened cotton as a water source. Alternative prey, such as the pupae of Tenebrio molitor L., 1785 (Coleoptera: Tenebrionidae), the larvae of Musca domestica L., 1758 (Diptera: Muscidae), and the Bombyx mori L., 1758 (Lepidoptera: Bombycidae) (Zanuncio et al. 2005, Neves et al. 2010) (Fig. 3) or the caterpillars of natural prey, such as the Anticarsia gemmatalis Hübner, 1818 (Lepidoptera: Noctuidae), Thyrinteina arnobia Stoll, 1782, and Thyrinteina leucocerae Rindge, 1961 (Lepidoptera: Geometridae) (Ferreira et al. 2008, Oliveira et al. 2011) may be provided to the nymphs of predators in the cages and/or rearing bags. The nymph period of $P$. nigrispinus was similar to the T. molitor pupae (T1) and $M$. domestica larvae (T2) or with both prey simultaneously (T3) or in alternated days (T4) with an average viability of $75 \%$. Females were heavier in T1 and T4, although with similar reproductive rate. Females of these predators produced the highest number of eggs and nymphs with both preys simultaneously (Zanuncio et al. 2001).

Tenebrio molitor can be reared in plastic trays of different sizes with 95\% wheat bran (high carbohydrate) and $5 \%$ beer yeast (rich in proteins). Slices of Sechium edule (Jacq.) Swartz (Cucurbitaceae) and Saccharum spp. (Poaceae) are placed on the substrate as a moisture source with a paper towel covering it to reduce brightness.

Three hundred grams of $M$. domestica pupae are needed to start a rearing facility with a capacity of 10,000 flies. This material can yield 2.5 to $3 \mathrm{~kg}$ of larvae per day with young adult flies fed with milk and sugar. A tray with moistened wheat bran with water and milk is placed inside the nursery as an oviposition site. The tray with the substrate with postures is removed the next day and its contents placed in a rearing tray with slightly moistened wheat bran. The larvae can be transferred with a trowel the next day and offered to the predators.

Vallourec \& Mannesmann Forest Ltda. have trained personal to detect outbreaks of pests in the Eucalyptus spp. plantations. Natural enemies $[P$. nigrispinus and/or Palmistichus elaeisis Delvare \& LaSalle, 1993 (Hymenoptera: Eulophidae)] are released in these areas when monitoring detects and indicates population levels of larvae and/or the pupae of insect pests. The predator P. nigrispinus is released in plantations with larvae of defoliators and

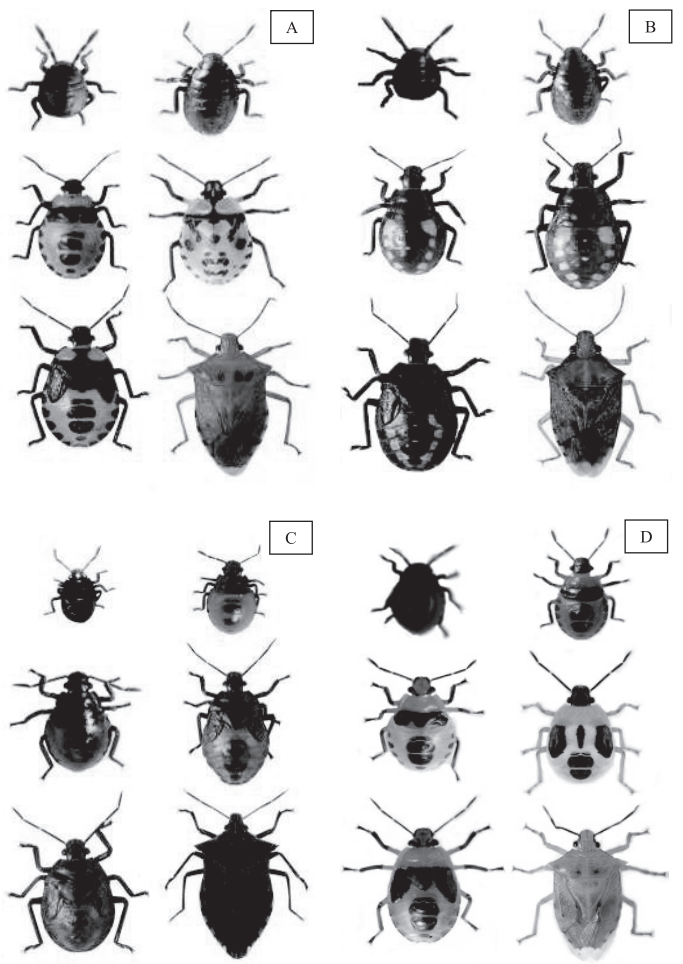

Fig. 1. Nymphs of first, second, third, fourth, and fifth instar and adults of (A) Brontocoris tabidus, (B) Podisus nigrispinus, (C) Podisus distinctus, and (D) Supputius cincticeps (Heteroptera: Pentatomidae).

P. elaiseis when pupae are present.

The natural enemies are transported to the field in coolers. Podisus nigrispinus is usually released in outbreaks of caterpillars. Then 2,000 to 5,000 third instar nymphs of $P$. nigrispinus are released per week from 8:00 to 16:00.

Pest population fluctuation is monitored weekly and the data recorded until caterpillar outbreaks are finished. A population survey and level of economic damage are determined in nine Eucalyptus spp. trees homogeneously distributed inside the area. A total of 100 leaves per plot are taken from the lowermiddle part of small trees or those with a dominate canopy. The number and stage of larvae on these leaves are evaluated. If the number of natural enemies available is more than those necessary for release in caterpillar outbreaks they are released in areas with a history of pest occurrence, even in the absence of them.

\section{RESULTS AND DISCUSSION}

Lepidoptera defoliators can be controlled at egg and larva stages in the field by nymphs and adult Asopinae predators. Pupae of these pests can also be controlled by nymph and adult predators (Zanuncio 

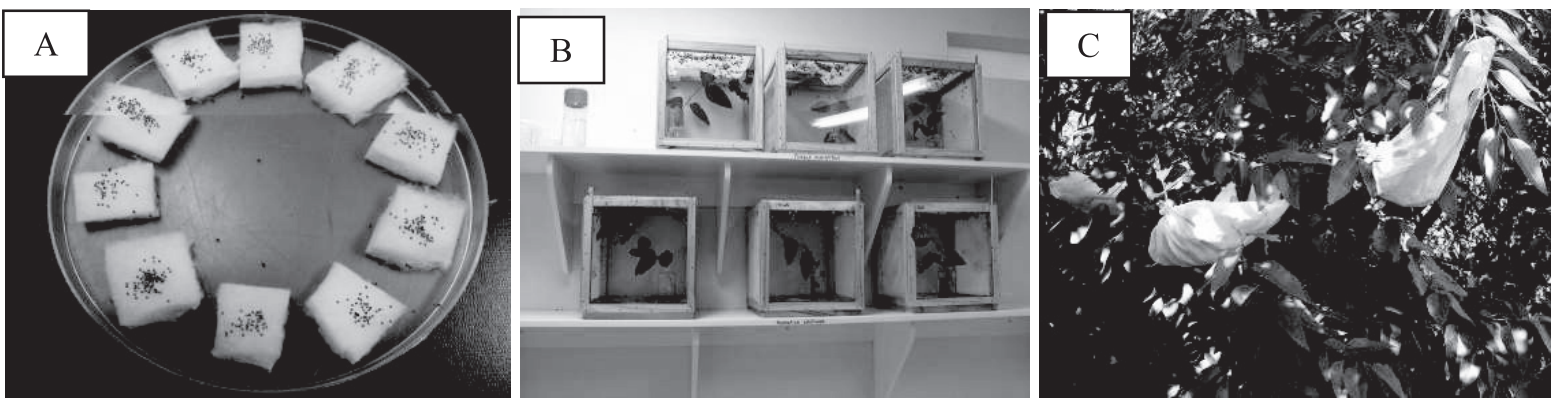

Fig 2. (A) Petri dish with eggs on pieces of cotton, (B) wooden cages with branches of Eucalyptus grandis W.Hill ex Maiden (Myrtaceae), and (C) organza bags involving branches of this plant in the field to rearing Asopinae predators.
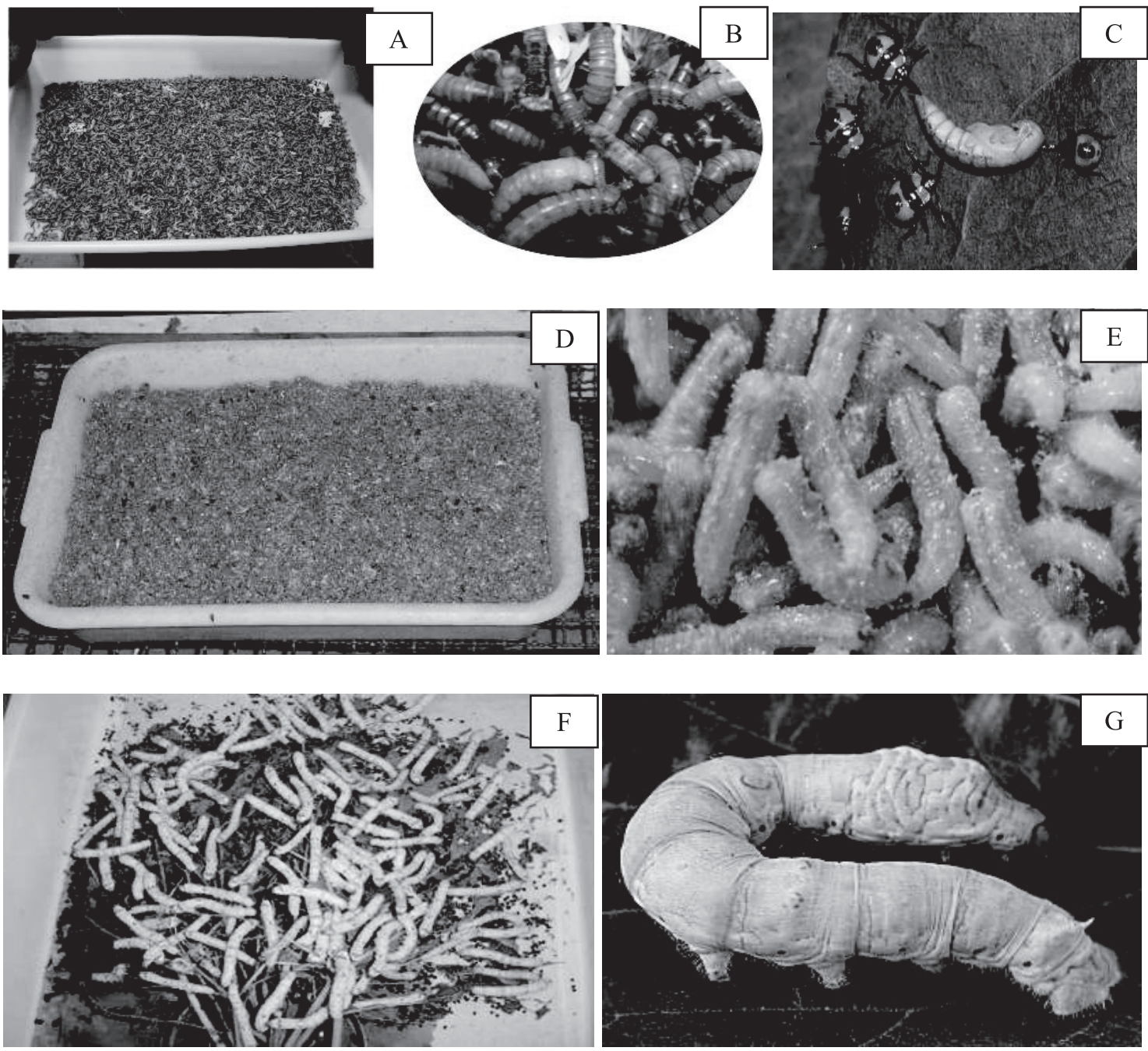

Fig 3. (A)Plastic tray with (B) larvae and pupae of Tenebrio molitor (Coleoptera: Tenebrionidae) and Brontocoris tabidus (Heteroptera: Pentatomidae), (C) nymphs preying on larvae of this prey, (D) Plastic tray with (E) Musca domestica (Diptera: Muscidae) larvae, and (F) Plastic tray with branches of Morus sp. (Moraceae) as a substrate to feed (G) Bombyx mori (Lepidoptera: Bombycidae) caterpillars.

et al. 2008) (Fig. 4) and by parasitoids as P. elaeisis and Trichospilus diatraeae Margabandhu and Cherian, 1942 (Hymenoptera: Eulophidae) (Pereira et al. 2008, Andrade et al. 2010). Brontocoris tabidus is the first to arrive in areas infested by defoliating caterpillars, followed by other predatory species, especially $P$. nigrispinus. These natural enemies build large populations when egg parasitoids start to 

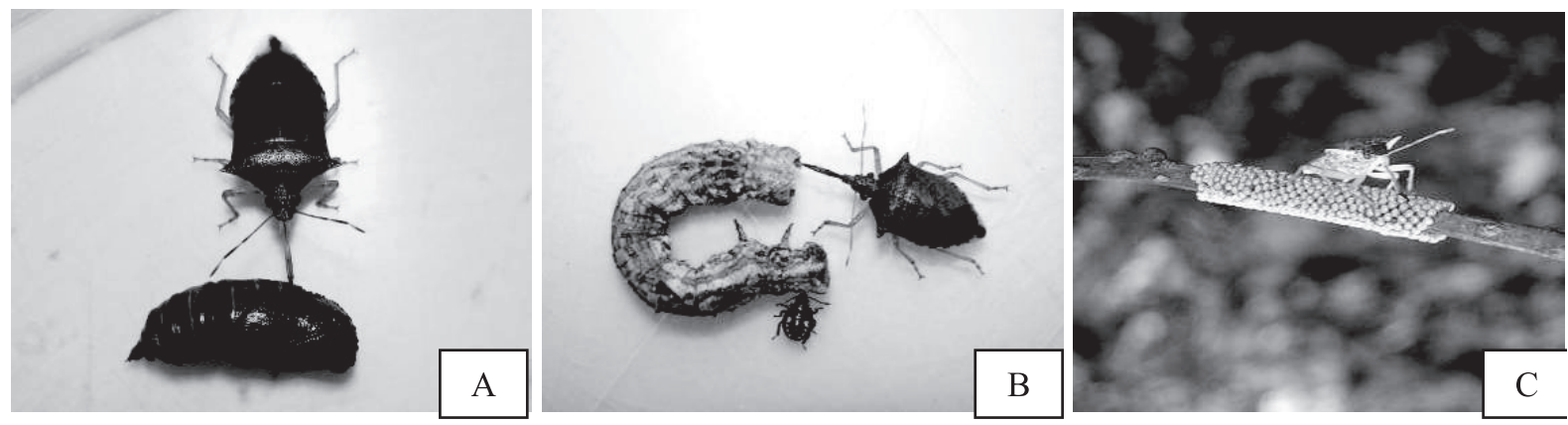

Fig. 4. (A) Asopinae predators feeding on pupa and (B) caterpillar in the laboratory, and (C) eggs of Lepidoptera defoliators in the field.

Annual releases of Podisus nigrispinus 1991-2011

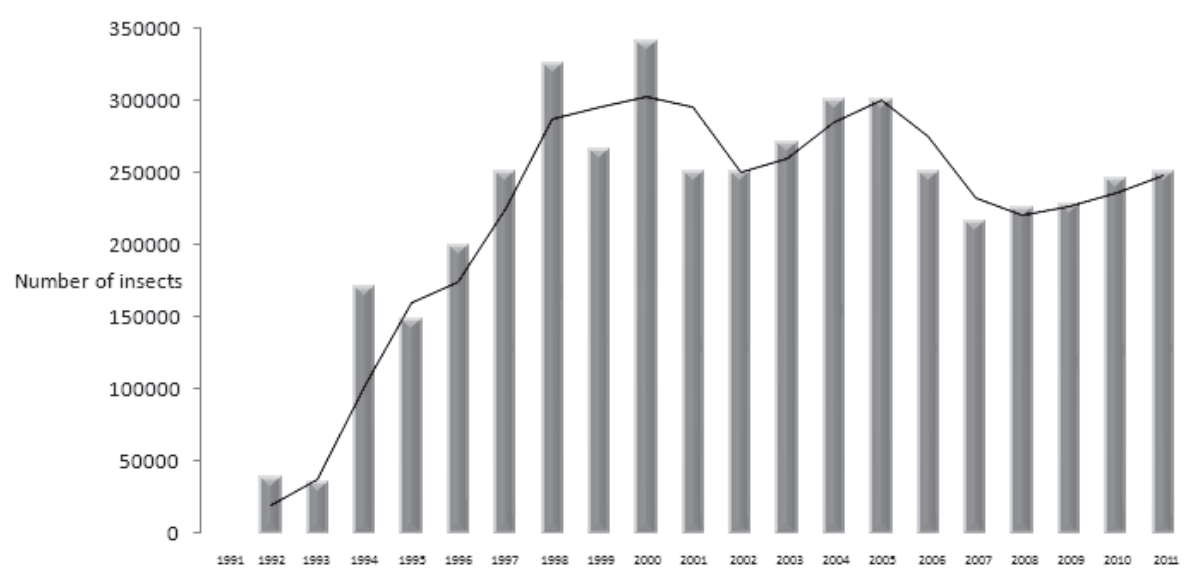

Fig. 4. Number of individuals of Podisus nigrispinus (Heteroptera: Pentatomidae) released from 1991 to 2011 in the Eucalyptus spp. (Myrtaceae) plantations of the Vallourec \& Mannesmann Forest Ltda. in Minas Gerais State, Brazil.

reduce their populations (Soares et al. 2009). Barriers with spraying products based on Bacillus thuringiensis Berliner, 1915 (Bacillales: Bacillaceae) (Polanczyk et al. 2009) are made around pest outbreaks to reduce its spread.

The diversity of natural enemies is an alternative in integrated pest management (IPM). The emergence and the cycle from egg to adult of $P$. elaeisis parasitizing pupae of T. molitor predated by $P$. nigrispinus for $48 \mathrm{~h}$ showed lower values compared to $24 \mathrm{~h}$, but the female parasitoid that emerged had a longer lifespan. Predation of pupae parasitized by P. elaeisis reduced the emergence and sex ratio, but the increased longevity of this parasitoid, may reduce its populations in the field. Moreover, shorter immature stage and increased longevity of $P$. elaeisis could benefit the impact of this parasitoid in the field with the predator P. nigrispinus (Soares 2010).

Vallourec \& Mannesmann Forest Ltda. is a pioneer company in Brazil using biological control for pest management in the Eucalyptus spp. plantations. The first laboratory of biological control was built at the Support Centre for Research and Forest Development (CAPEF) in Paraopeba, Minas Gerais State, Brazil in 1989 to mass produce and release $P$. nigrispinus to control outbreaks of Apatelodes sericea Schaus, 1896 (Lepidoptera: Eupterotidae), Glena spp. (Lepidoptera: Geometridae), Psorocampa denticulata Schaus, 1901 (Lepidoptera: Notodontidae), and T. arnobia, besides other lepidopteran species (Zanuncio et al. 2003, Freitas et al. 2005). This is important because yield losses between 5 and 10\% were recorded for trees with 75 and $100 \%$ defoliation, respectively, and therefore pest control is important to maintain wood productivity. Biological control is an effective and sustainable pest management method because it reduces the population levels of pests and the number of chemical applications (Elek et al. 2003, 
Mansfield et al. 2006).

Podisus nigrispinus is preferable for mass rearing and pest control in Eucalyptus spp. plantations because it presents a well developed and efficient production technique compared to other Asopinae, besides having more eggs per female with higher predation rates and short life cycle and it can be fed an artificial diet during periods of prey shortage (Ramalho et al. 2008). Vallourec \& Mannesmann Forest Ltda. has two laboratories to mass rear $M$. domestica with an average annual production of 300,000 predators (Fig. 5). Environment conditions affect the duration of the life cycle of predators and, therefore, temperature, relative humidity, and photoperiod should be controlled (Medeiros et al. 2003, 2004).

Podisus nigrispinus is released with or without pests in the field. In the first case, predators are released after detection of the pest by the monitoring process, which is the first major step in IPM. This predator is efficient when pest population level is below the economic injury level, i.e., nine caterpillars/100 leaves of Eucalyptus spp. Releasings are made in outbreaks every $10 \mathrm{~m}$. Podisus nigrispinus usually prey on four to five first and second instars larvae or two to three fourth and fifth instar caterpillars per day. A total of 1.500 ha of Eucalyptus spp. with an outbreak of the defoliating caterpillars Thyrinteina spp. and Glena spp. was controlled with $P$. nigrispinus in the first three months of 2012. It is necessary to point that this control prevented an increase in the area damaged by defoliating caterpillars and to adjacent eucalyptus plantations.

Occurrence of larvae and damage is usually more severe in Eucalyptus spp. from seeds when the plants are between three and four years old. On the other hand, plantations with clones, such as most grown in Brazil, have a more advanced technological level and are generally infested by defoliator caterpillars when they are one to two years old. Therefore, prevention measures against caterpillar defoliators are higher in clone plantations of Eucalyptus spp. These insects, normally, have larger populations during months of low rainfall, water deficit, and lower relative humidity.

Asopinae predators are reared and released in the field to control pests in Eucalyptus spp. plantations of the Vallourec \& Mannesmann Forest Ltda. in Brazil.

\section{ACKNOWLEDGEMENTS}

To the Brazilian agencies "Conselho Nacional de Desenvolvimento Científico e Tecnológico (CNPq)", "Coordenação de Aperfeiçoamento de Pessoal de Nível Superior (CAPES)" and "Fundação de Amparo a Pesquisa do Estado de Minas Gerais (FAPEMIG)" for financial support.

\section{REFERENCES}

Andrade GS, Serrao JE, Zanuncio JC, Zanuncio TV, Leite GLD, Polanczky RA (2010) Immunity of an alternative host can be overcome by higher densities of its parasitoids Palmistichus elaeisis and Trichospilus diatraeae. PLoS ONE e13231.

Elek JA, Steinbauer MJ, Beveridge N, Ebner P (2003) The efficacy of high and low volume spray applications of Mimic (R) (tebufenozide) for managing autumn gum moth larvae Mnesampela privata (Lepidoptera: Geometridae) in eucalypt plantations. Agricultural and Forest Entomology 5: 325-332.

Ferreira JAM, Zanuncio JC, Torres JB, Molina-Rugama AJ (2008) Predatory behaviour of Podisus nigrispinus (Heteroptera: Pentatomidae) on different densities of Anticarsia gemmatalis (Lepidoptera: Noctuidae) larvae. Biocontrol Science and Technology 18: 711-719.

Freitas FA, Zanuncio TV, Zanuncio JC, Conceição PM, Fialho MDQ, Bernardino AS (2005) Effect of plant age, temperature and rainfall on Lepidoptera insect pests collected with light traps in a Eucalyptus grandis plantation in Brazil. Annals of Forest Science 62: 85-90.

Lemos WP, Zanuncio JC, Ramalho FS, Serrão JE (2009a) Fat body of the zoophytophagous predator Brontocoris tabidus (Het.: Pentatomidae) females: Impact of the herbivory and age. Micron 40: 635-638.

Lemos WP, Zanuncio JC, Ramalho FS, Zanuncio VV, Serrão JE (2010a) Herbivory affects ovarian development in the zoophytophagous predator Brontocoris tabidus (Heteroptera, Pentatomidae). Journal of Pest Science 83: 69-76. 
Lemos WP, Zanuncio VV, Ramalho FS, Zanuncio JC, Serrão JE (2010b) Ovary histology of the predator Brontocoris tabidus (Hemiptera: Pentatomidae) of two ages fed on different diets. Entomological News 121: 230235.

Lemos WP, Serrão JE, Zanuncio JC, Lacerda MC, Zanuncio VV, Ribeiro RC (2009b) Body weight and protein content in the haemolymph of females of the zoophytophagous predator Brontocoris tabidus (Heteroptera: Pentatomidae) with different diets and ages. Journal of Plant Diseases and Protection 116: 218222.

Mansfield S, Withers TM, Gous SF, Potter KJB, Kriticos DJ, Watson MC, Kimberley MO (2006) Potential of selective insecticides for managing Uraba lugens (Lepidoptera: Nolidae) on eucalypts. Journal of Economic Entomology 99: 780-789.

Medeiros RS, Ramalho FS, Serrão JE, Zanuncio JC (2003) Temperature influence on the reproduction of Podisus nigrispinus, a predator of the noctuid larva Alabama argillacea. BioControl 48: 695-704.

Medeiros RS, Silva AMC, Zanuncio JC, Ramalho FD, Serrão JE, Cecon PR (2004) Oviposition pattern of the predator Podisus nigrispinus (Heteroptera: Pentatomidae) under different temperatures. Biocontrol Science and Technology 14: 487-498.

Neves RCD, Torres JB, Zanuncio JC (2010) Production and storage of mealworm beetle as prey for predatory stinkbug. Biocontrol Science and Technology 20: 1013-1025.

Oliveira HN, Espindula MC, Duarte MM, Pereira FF, Zanuncio JC (2011) Development and reproduction of Podisus nigrispinus (Hemiptera: Pentatomidae) fed with Thyrinteina arnobia (Lepidoptera: Geometridae) reared on guava leaves. Brazilian Archives of Biology and Technology 54: 429-434.

Pereira FF, Zanuncio TV, Zanuncio JC, Pratissoli D, Tavares MT (2008) Species of Lepidoptera defoliators of Eucalyptus as new host for the parasitoid Palmistichus elaeisis (Hymenoptera: Eulophidae). Brazilian Archives of Biology and Technology 51: 259-262.

Pires EM, Zanuncio JC, Serrão JE (2011) Cannibalism of Brontocoris tabidus and Podisus nigrispinus during periods of pre-release without food or fed with Eucalyptus cloeziana plants. Phytoparasitica 39: 27-34.

Polanczyk RA, Zanuncio JC, Alves SB (2009) Relationship between chemical properties of the soil and the occurrence of Bacillus thuringiensis. Ciência Rural 39: 1-5.

Ramalho FS, Mezzomo J, Lemos WP, Bandeira CM, Malaquias JB, Silva JPS, Leite GLD, Zanuncio JC (2008) Reproductive strategy of Podisus nigrispinus females under different feeding intervals. Phytoparasitica 36: $30-37$.

Soares MA, Batista JD, Zanuncio JC, Lino-Neto J, Serrão JE (2011) Ovary development, egg production and oviposition for mated and virgin females of the predator Podisus nigrispinus (Heteroptera: Pentatomidae). Acta Scientiarum. Agronomy 33: 597-602.

Soares MA (2010) Interactions among the predator Podisus nigrispinus (Heteroptera: Pentatomidae) and the parasitoid Palmistichus elaeisis (Hymenoptera: Eulophidae). PhD Thesis Scientiae in Entomology. Federal University of Viçosa (UFV), Viçosa, Minas Gerais State, Brazil.

Soares MA, Zanuncio JC, Leite GLD, Wermelinger ED, Serrao JE (2009) Does Thyrinteina arnobia (Lepidoptera: Geometridae) use different defense behaviours against predators? Journal of Plant Diseases and Protection 116: 30-33.

Souza GK, Pikart TG, Pikart FC, Serrão JE, Wilcken CF, Zanuncio JC (2012) First record of a native heteropteran preying on the introduced pest, Thaumastocoris peregrinus (Hemiptera: Thaumastocoridae), in Brazil. Florida Entomologist 95: 517-520.

Zanuncio JC, Molina-Rugama AJ, Serrão JE, Pratissoli D (2001) Nymphal development and reproduction of Podisus nigrispinus (Heteroptera: Pentatomidae) fed with combinations of Tenebrio molitor (Coleoptera: Tenebrionidae) pupae and Musca domestica (Diptera: Muscidae) larvae. Biocontrol Science and Technology 11: 331-337. 
Zanuncio JC, Zanuncio TV, Freitas FA, Pratissoli D (2003) Population density of Lepidoptera in a plantation of Eucalyptus urophylla in the state of Minas Gerais, Brazil. Animal Biology 53: 17-26.

Zanuncio JC, Beserra EB, Molina-Rugama AJ, Zanuncio TV, Pinon TBM, Maffia VP (2005) Reproduction and longevity of Supputius cincticeps (Het.: Pentatomidae) fed with larvae of Zophobas confusa, Tenebrio molitor (Col.: Tenebrionidae) or Musca domestica (Dip.: Muscidae). Brazilian Archives of Biology and Technology 48: 771-777.

Zanuncio JC, Silva CA, Lima ER, Pereira FF, Ramalho FD, Serrão JE (2008) Predation rate of Spodoptera frugiperda (Lepidoptera: Noctuidae) larvae with and without defense by Podisus nigrispinus (Heteroptera: Pentatomidae). Brazilian Archives of Biology and Technology 51: 121-125. 